RICHARD N. COOPER

Harvard University

\title{
Is the U.S. Current Account Deficit Sustainable? Will It Be Sustained?
}

IT IS ESTIMATED that in 2001 the U.S. current account deficit will reach $\$ 450$ billion, or 4.4 percent of GDP, up from 3.6 percent in $1999 .{ }^{1}$ Current account balance was last achieved in 1991 (1981 if Gulf War-related special receipts are excluded for 1991). One has to go back to the two decades before 1914, a period of mass immigration and extensive infrastructure construction, to find deficits even approximately as large, relative to GDP, as those of recent years. ${ }^{2}$ The United States is reckoned, by global standards, to be a country relatively rich in capital. Why, then, is it importing more capital than ever before? Are deficits on this scale sustainable? Are they likely to be sustained?

\section{The Size and Significance of the Current Account Deficit}

It is useful to put the U.S. deficit into its global context; foreign trade, after all, is with other countries. In 1999 (the latest year for which world-

1. U.S. net exports in the national accounts were $\$ 254$ billion in 1999 , or 2.7 percent of GDP. Apart from relatively minor adjustments to trade for coverage and timing, the current account in the balance of payments includes net earnings (net payments since 1998) on foreign investment and net transfers to foreigners, which do not affect GDP. For international comparability, I will use figures from the balance of payments accounts rather than the national income accounts.

2. The U.S. current account deficit reached an estimated 3.3 percent of GDP in 1872, and 2.3 percent in 1888 (calculated from Historical Statistics of the United States, 1975); the current account was mostly balanced over the period $1885-1913$, averaging +0.1 percent of GDP in those years, according to Jones and Obstfeld (1997). 
wide data are available) the U.S. deficit, at $\$ 331$ billion, dwarfed all others. Brazil was the runner-up with $\$ 25$ billion; Poland and Argentina each had deficits of $\$ 12$ billion. Japan had the largest surplus at \$107 billion (2.5 percent of its GDP), followed by Russia and the Republic of Korea—both still reeling from financial crises - with roughly $\$ 25$ billion each (13.7 percent and 6.0 percent of GDP, respectively) and China with $\$ 16$ billion (1.6 percent). Among these countries, Poland, Brazil, and Argentina had larger deficits than the United States relative to GDP, at 8.0 percent, 4.7 percent, and 4.3 percent, respectively. But some of the largest current account imbalances relative to GDP were recorded by smaller countries, including outsize surpluses in Singapore (25 percent), Kuwait (17 percent), and Norway (4 percent), and deficits in Côte d'Ivoire (3 percent) and Israel ( 2 percent).

But globally the numbers do not add up. In principle, the world should be in current account balance every period; in fact, the records show a deficit of $\$ 130$ billion for 1999, suggesting substantial underrecording of receipts. ${ }^{3}$ But where? Given its size in the world economy, it would be surprising if the United States were not receiving a substantial amount, net, of these unrecorded receipts. Thus the recorded deficit is undoubtedly exaggerated, perhaps by tens of billions of dollars. Even this correction, however, would still leave a U.S. deficit that is large by twentieth-century standards, and a dominating feature of the world economy in recent years, lending support to the claim that Americans are the world's consumers of last resort.

It is often suggested that the large current account deficit poses a serious financing problem for the United States. Each year, the lament goes, the United States must attract net inflows of capital sufficient to "cover" the huge current shortfall. But this proposition gets the logic backward: the U.S. deficit is "financed" by net capital inflows only in an ex post accounting sense. In economic terms it is more nearly correct to say that net capital inflows cause the current account deficit.

The currencies of most major U.S. trading partners - the Canadian dollar, the yen, the pound sterling, the deutsche mark (or the euro since 1999) — have been floating against the U.S. dollar since the early 1970s. Foreign trade in goods and services is determined by many factors, among them exchange rates. Exchange rates in turn are determined by, among other things, the net purchases of financial and other assets denominated in 
each currency. Net purchases of dollar-denominated assets (which need not be domiciled in the United States) will, ceteris paribus, push up the value of the dollar relative to the currency being exchanged for dollars to purchase those assets.

The United States has no controls of any consequence on the inflow or outflow of capital —on purchases of foreign assets by Americans, or of American assets by non-Americans. The basic story of the past two decades is that, on balance, foreigners have wanted to buy more American assets than Americans have wanted to invest abroad. This imbalanced tendency increased during the early 1980s, leading to a peak in the current account deficit of $\$ 161$ billion (3.4 percent of GDP) in 1987. The deficit then receded, crossed over into surplus territory (by $\$ 7$ billion) in 1991,4 and finally experienced a virtually uninterrupted year-to-year "deterioration" throughout the 1990s (table 1).

The language of current account deficits is unfortunate: it reverses the economic logic and suggests that in the U.S. case a deficit is undesirable, even though it reflects a vote of confidence by the rest of the world in the United States, or at least in claims on Americans. Put another way, the United States has demonstrated strong comparative advantage in exporting stocks, bonds, bank deposits, and other claims on such U.S. assets as real estate and U.S.-domiciled firms under foreign management control (that is, foreign direct investment; see table 2). Foreign private parties invested $\$ 711$ billion, net of sales, in the United States during 1999, which rose to an astonishing $\$ 916$ billion in 2000; Americans invested $\$ 442$ billion abroad during 1999. ${ }^{5}$ Governments also invested abroad, although on a much smaller scale.

\section{Why So Large?}

Why do foreigners invest so much in the United States? The answer is not hard to find. The U.S. economy alone accounts for more than a quarter

4. The balance was still in deficit if $\$ 43$ billion in foreign payments to the United States for the Gulf War is excluded.

5. Of this figure, $\$ 78$ billion represented reinvested earnings. Reinvested earnings by foreigners, amounting to $\$ 26$ billion, are counted as current payments to foreigners, which are notionally offset by a corresponding capital inflow. 
Table 1. U.S. International Transactions, 1960-2000

Billions of dollars

\begin{tabular}{|c|c|c|c|c|c|c|c|}
\hline \multirow[b]{2}{*}{ Year } & \multicolumn{4}{|c|}{ Balance on } & \multirow{2}{*}{$\begin{array}{c}\text { U.S. } \\
\text { investment } \\
\text { abroad }^{\mathrm{b}}\end{array}$} & \multicolumn{2}{|c|}{$\begin{array}{c}\text { Foreign } \\
\text { investment } \\
\text { in the } \\
\text { United States }^{\mathrm{c}}\end{array}$} \\
\hline & $\begin{array}{l}\text { Current } \\
\text { account }\end{array}$ & Goods & Services & $\begin{array}{c}\text { Investment } \\
\text { income }^{\mathrm{a}}\end{array}$ & & Official & Other \\
\hline 1960 & 2.8 & 4.9 & -1.4 & 3.4 & -4.1 & 1.5 & 0.8 \\
\hline 1965 & 5.4 & 5.0 & -0.3 & 5.4 & -5.7 & 0.1 & 0.6 \\
\hline 1970 & 2.3 & 2.6 & -0.3 & 6.2 & -8.5 & 6.9 & -0.6 \\
\hline 1975 & 18.1 & 8.9 & 3.5 & 12.8 & -39.7 & 7.0 & 10.1 \\
\hline 1980 & 2.3 & -25.5 & 6.1 & 30.1 & -85.8 & 15.5 & 47.1 \\
\hline 1985 & -118.2 & -122.2 & 0.3 & 25.7 & -44.8 & -1.1 & 147.2 \\
\hline 1990 & -77.0 & -109.0 & 30.2 & 28.6 & -81.2 & 33.9 & 107.7 \\
\hline 1991 & 6.6 & -74.1 & 45.8 & 24.1 & -64.4 & 17.4 & 93.4 \\
\hline 1992 & -47.7 & -96.1 & 60.4 & 23.0 & -74.4 & 40.5 & 130.2 \\
\hline 1993 & -82.7 & -132.6 & 63.7 & 23.9 & -200.6 & 71.8 & 210.3 \\
\hline 1994 & -118.6 & -166.2 & 69.2 & 16.7 & -176.1 & 39.6 & 266.4 \\
\hline 1995 & -109.5 & -173.7 & 77.8 & 20.5 & -352.4 & 109.9 & 355.8 \\
\hline 1996 & -123.3 & -191.3 & 89.2 & 18.9 & -413.9 & 126.7 & 445.0 \\
\hline 1997 & -140.5 & -196.7 & 90.7 & 6.2 & -488.9 & 18.9 & 738.1 \\
\hline 1998 & -217.1 & -246.9 & 80.0 & -6.2 & -335.4 & -20.1 & 502.4 \\
\hline 1999 & -331.5 & -345.6 & 80.6 & -18.5 & -430.2 & 42.9 & 710.7 \\
\hline 2000 & -435.4 & -449.5 & 81.0 & -13.7 & -553.3 & 35.9 & 916.5 \\
\hline
\end{tabular}

Source: Bureau of Economic Analysis, International Transactions Accounts.

a. Net of income received on U.S. assets minus payments on U.S. assets abroad.

b. Change in U.S.-owned assets located abroad.

c. Change in foreign-owned assets located in the United States.

of the world economy, its fundamentals are strong, and it performs well. Nearly half of all foreign claims on the United States are interest bearing, and U.S. interest rates in recent years have been higher than those in Europe, and much higher than in Japan. This has allowed the United States to attract and hold funds from those areas and elsewhere. Other parts of the world have been through financial crises, resulting in higher interest rates, but also in much greater uncertainty about their exchange rates and even the prospect of repayment.

Returns on equity capital also tend to be higher in the United States than in Europe and Japan, and more reliable than in many developing countries. In 1997, for instance, the business sector capital-output ratio in the United 
Table 2. U.S. International Investment Position, 1979-99a

Billions of dollars

\begin{tabular}{|c|c|c|c|}
\hline Asset & 1979 & 1989 & 1999 \\
\hline U.S.-owned assets abroad & 508.9 & $1,944.2$ & $7,173.4$ \\
\hline Official reserves & 19.0 & 168.7 & 136.4 \\
\hline Other government & 58.4 & 84.2 & 84.2 \\
\hline Private $^{\mathrm{b}}$ & 431.5 & $1,691.3$ & $6,952.7$ \\
\hline Foreign direct investment ${ }^{\mathrm{b}}$ & $186.8^{\mathrm{c}}$ & 807.7 & $2,615.5$ \\
\hline Bonds & & 98.5 & 556.7 \\
\hline Corporate stocks & 56.6 & 91.7 & $2,026.6$ \\
\hline Other & 188.1 & 642.2 & $1,753.8$ \\
\hline Foreign-owned assets in the United States ${ }^{\mathrm{b}}$ & 413.9 & $2,211.9$ & $8,647.1$ \\
\hline Foreign official & 159.5 & 337.3 & 869.3 \\
\hline U.S. government securities & 106.6 & 265.7 & 628.9 \\
\hline Other & 9.9 & 9.6 & 50.7 \\
\hline Private $^{\mathrm{b}}$ & 254.4 & $1,874.7$ & $7,777.7$ \\
\hline Foreign direct investment ${ }^{\mathrm{b}}$ & 54.5 & 533.5 & $2,800.7$ \\
\hline Bonds $^{\mathrm{d}}$ & & 228.5 & $1,063.7$ \\
\hline Stocks & 58.6 & 260.6 & $1,445.6$ \\
\hline U.S. currency & n.a. & 40.4 & 473.8 \\
\hline Other & 127.2 & 648.7 & $1,556.3$ \\
\hline Net U.S. international investment position & 95.0 & -267.7 & $-1,473.7$ \\
\hline
\end{tabular}

Source: Economic Report of the President, various years.

a. End of period, selected years.

b. At market prices, except where noted otherwise.

c. At book value.

d. Includes marketable short-term U.S. Treasury securities.

States, at 1.3, was lower than that in any other advanced industrial country, and less than half that in France, Germany, Japan, or the United Kingdom. ${ }^{6}$ A series of industry-level productivity studies by McKinsey \& Company also report significantly higher returns to capital in the United States than in other industrial countries, and indeed than in some developing countries.

Moreover, because of the size and character of U.S. markets, stocks and bonds traded on them tend to be more liquid, as measured by transactions costs, than those in most other markets. And the U.S. public

6. Organization for Economic Cooperation and Development, OECD in Figures, 1998, pp.14-15. An "advanced industrial country" here is defined as a member of that organization in 1994. 
markets are considered to offer better protection for creditors and minority shareholders, and against insider trading, than those in most other countries. In short, investments in America are viewed favorably around the world, and for good reason: the U.S. economy is a good, steady performer, less sluggish than Europe and Japan, less volatile than emerging markets. Inflows of investment funds therefore push up the dollar-and this, in turn, makes foreign goods more competitive and pushes up the current account deficit.

Like all investments, some will go bad, and foreigners will lose their money, as some surely did on real estate purchased in the late 1980s and on stock purchased in the late 1990s. But on balance the claims will generate future income, especially for aging Japanese and Europeans. When they eventually withdraw their accumulated savings, U.S. exports will be stimulated by a consequently weaker dollar. Until then, American obligations to the rest of the world will grow.

Investment by foreigners in the United States serves them well. It is also good for Americans, so long as Americans invest in improved productive capacity and innovation in the U.S. economy. If investment projects in the United States yield 10 to 15 percent, as many do, and U.S. obligations to foreigners issued to finance those projects yield 5 to 10 percent, as many do, all will benefit.

Business investment in the U.S. economy has recently been strong, reaching 12.9 percent of GDP in 1999, the highest level in many years, and up from below 11 percent in the recovery years 1993-94. In the 1980 s it could be said that foreign capital financed the U.S. budget deficit rather than private investment (and indeed there were many foreign purchases of U.S. government bonds). By 1998, however, the federal government was running a surplus, which has risen substantially since then; state and local governments have also run growing surpluses. Thus the foreign contribution to U.S. saving permitted both some increase in business investment and some decline in household saving rates.

In the meantime, however, some American businesses found themselves under severe competitive pressure from foreign goods, which was not fully offset by increased foreign demand for U.S. exports. That resulted in political pressure for increased protection and in increasing abuse of the antidumping provisions of U.S. trade law, which were not designed to cope with fluctuating exchange rates. 


\section{How Sustainable?}

How sustainable is the U.S. deficit? Put another way, how long will foreigners be willing to invest an additional $\$ 400$ billion a year, year after year, in the United States, net of U.S. investment flows abroad? Gross world saving outside the United States probably exceeded $\$ 5$ trillion in 2000, implying a world (ex-U.S.) saving rate of 22 percent. The U.S. deficit, at $\$ 400$ billion, was equal to 8 percent of that $\$ 5$ trillion. It is not beyond imagination that foreigners will want to continue to invest 8 percent of their annual saving in the United States. After all, the United States in 1999 accounted for over 28 percent of gross world product, ${ }^{7}$ and its listed securities account for nearly half the world's total by value. ${ }^{8}$ Foreign investment in the United States would have to be a few percentage points above 8 percent to allow net investment by Americans in the rest of the world to continue at current levels, in a continuing process of diversification, but even that falls comfortably within the range of plausibility. Another way to look at the issue: Americans would have had to invest 44 percent of their total national saving abroad in 1999 to achieve current account balance, given the foreign capital that flowed into the United States.

To repeat, investments in the United States have provided, and are likely to continue to provide, returns that are both high and reliable compared with most other parts of the world, where they are either reliable but low, or sometimes high but unreliable. In short, extensive foreign investment in the United States makes economic sense. In the fundamental (but not politically correct) sense of the term, the United States is a developing country, particularly compared with aging Europe and Japan.

\section{How Likely to Be Sustained? And by Whom?}

Will the deficit be sustained? Perhaps not, at least by private capital alone, the above analysis notwithstanding. Suppose private foreigners

7. World Bank, World Development Report 2000/2001, p. 275.

8. Statistical Abstract of the United States 1998, table 1385; Bank for International Settlements, International Banking and Financial Market Developments, August 2000, table 16A). 
collectively decided to invest less in the United States than is required to "finance" a current account deficit on the order of $\$ 400$ billion, plus perhaps $\$ 100$ billion to $\$ 200$ billion to allow for net investment abroad by Americans. Because of inertia leading to response lags, the current account deficit would not at once drop in parallel with the decline in private net capital inflows. What would be the consequence? The dollar would depreciate, making foreign goods more expensive for Americans and making U.S. products more competitive in world markets. In time, the U.S. current account deficit would decline to match the remaining net foreign investment in the United States. A cheaper dollar would also make some investments in the United States even more attractive, drawing new capital inflows.

Given the lags, however, and the fragility of expectations in financial and especially in foreign exchange markets, it is possible, indeed likely, that the dollar would depreciate further than necessary to correct the underlying imbalance. Cries of alarm would then appear in the financial press and in other quarters. There would be grim headlines, and pundits would pronounce the early end of the new American century. Prospective foreign investment might hesitate, waiting for an even cheaper dollar, thereby pushing the dollar further downward.

However, excessive depreciation of the dollar is likely to alarm foreign exporters, and their governments, more than it alarms knowledgeable Americans. Many American firms, of course, would welcome it. In the end, however, foreign central banks would be likely to intervene in foreign exchange markets to brake a large fall in the dollar, in effect supplementing foreign private investment in the United States with foreign official investment. That is how world official foreign exchange reserves rose to their 1999 magnitude of $\$ 1.9$ trillion, around two-thirds of which is held in U.S. dollars. This has happened even though exchange rates among major currencies have been floating for more than twenty-five years, supposedly (at least according to some economists in the early 1970s) eliminating the need for official reserves.

Do we want to rely entirely on foreign officials to stem a sharp drop in the dollar, if it occurs? Can they be relied on? Japan has shown a reliable willingness to intervene in foreign exchange markets to prevent a too rapid or too extensive appreciation of the yen, and in the process it has built up $\$ 350$ billion in official reserves, most, presumably, in U.S. government securities. The new European Central Bank (ECB), for its part, 
has demonstrated a marked reluctance to intervene in foreign exchange markets despite a substantial depreciation of the euro from $\$ 1.17$ when it was introduced in January 1999. A flurry of intervention in the fall of 2000 earned the ECB criticism both from those who oppose intervention on principle and from those who questioned its handling of the episode. The German Bundesbank had been charged with ensuring the "stability of the currency," an artful phrase; the ECB is more narrowly charged with ensuring price stability, which leaves less room for maneuver, and this will make it reluctant to intervene in foreign exchange markets on a substantial scale.

However, currency depreciations and currency appreciations differ importantly in their domestic impacts, and it is an appreciation of the euro (and depreciation of the dollar) that is contemplated here. Could the ECB have stayed aloof from the foreign exchange market if, instead of depreciating by over 25 percent from its inauguration, it had appreciated by 25 percent, from $\$ 1.17$ to $\$ 1.46$ ? I doubt it. The deflationary pressure on an economically fragile Europe would have been too great to be politically bearable.

The ECB would probably be relaxed about a return of the euro to the neighborhood of $\$ 1.17$ and even higher, but European business and agriculture would chafe even at that, and they would protest loudly at any appreciation substantially beyond that rate. They would press both for greater monetary ease and for increased protection, for example through the (mis)use of antidumping duties. And that would put Europe in a position similar to that of the United States in 1985, when the "hands-off" Reagan administration reversed course and called for weakening the dollar, in part through foreign exchange market intervention.

The resulting Plaza Accord of 1985 called for coordinated intervention by the United States, Japan, and several European countries to counter the strong dollar. In the hypothesized future circumstance of a weakening dollar, Europe and Japan would intervene by selling their currencies and buying dollars. Selling one's own currency involves no drawdown of limited foreign exchange reserves. But to engage in a coordinated intervention, the United States would need foreign currency to sell. What resources could it draw on to intervene with? In 2000 U.S. monetary authorities held over $\$ 40$ billion in foreign exchange reserves and special drawing rights (SDRs), and the United States had another $\$ 15$ billion in its reserve position at the International Monetary Fund, plus $\$ 11$ billion in gold 
valued at $\$ 42$ an ounce. It could also borrow from the Fund, where its quota is $\$ 48$ billion (SDR37 billion at $\$ 1.30$ to the SDR).

But international capital flows have become massive, with the potential for massive reversal. The United States would be more comfortable if its holdings of foreign exchange reserves were greater. This suggests that the U.S. authorities should now be acquiring additional foreign exchange, especially euros and possibly yen, for future use. These currencies have the advantage of being relatively cheap (or were at the time of the March Brookings Panel meeting). Some yield would be sacrificed on the euros, and much on the yen, relative to U.S. Treasuries, but that would be recouped by a capital gain under the hypothesized circumstance of a significantly depreciated dollar.

The purchase of euros and yen today would itself put some downward pressure on the dollar, reducing some of the exchange rate pressures on U.S. producers, at a time when some export stimulus would be helpful. And the purchases would provide the Federal Reserve with some experience in undertaking open market operations in vehicles other than Treasuries, something it will eventually need in any case if the marketable federal debt is paid off. The administration and Congress are, however, making that prospect less likely with their proposed tax reductions, thus pushing the need for Federal Reserve adaptation further into the future. 